\title{
Augustus and the Problem of the Pax Deorum - A Case Study in Social \& Religious Motives at the Birth of the Roman Empire
}

\begin{abstract}
By David P. Wick ${ }^{*}$
The Emperor Augustus would believe at the end of his life that he had rekindled at least a functioning image of the archaic Roman religious spirit in the major arteries of his empire and at least in his city. His contemporaries seem to have agreed that they could see this happening, even when they acknowledged it as an act of propaganda in some sort. Modern scholars have been more inclined to see through it. This study approaches the question of the 'new era' after Actium from both the viewpoints of religious anxiety in original sources and also what roles or avenues of approach the newly-named Augustus might have had to work with, politically and in popular religion or moral reform. His earliest role, as 'avenger of Caesar', would have been entirely destructive and preserved the violence of feeling that rose in the Civil Wars. Role-playing Alexander, the 'Hercules' of popular myth, even ultimately a devotion to Apollo, all seemed inadequate. Instead, his road led him to create the groundwork for an attempt at a culture-wide 'religious revival', a construct we do not normally think native to the classical world, and which the sequel to this study hopes to pursue as it unfolded in actual practice.
\end{abstract}

Keywords: Ancient Studies, Roman Religion, political/social history, Augustus, Early Roman Empire.

\section{Introduction}

The Emperor Augustus would believe at the end of his life that he had rekindled at least a functioning image of the archaic Roman religious spirit in the major arteries of his empire and at least in his city. His contemporaries seem to have agreed that they could see this happening, even when they acknowledged it as an act of propaganda in some sort. Modern scholars have been more inclined to see through it.

Most modern attempts, in fact, to understand what are usually called the "Augustan religious reforms" seem to begin as acts of external political or rhetorical criticism -- the dissection of public language (including public activity treated as language) diagnosed as propaganda, $\mathrm{x}$-rayed by post-modernist semantics, and thinly sliced to reveal layers of subtext on the operating table. I propose in this brief study to hazard the experiment of beginning to reverse that approach. If we were to assume for the sake of argument that Augustus really valued (or had come to value) a change in the religious fabric of his times, and so watch some of his propaganda in action -- suspending our deconstructing tendencies long enough to take it on its own terms, would we understand it differently? Would we write about Augustus differently? There is a useful

*Professor, Gordon College, USA. 
preamble for this experiment in C.S. Lewis's inaugural Cambridge address:

\begin{abstract}
"The change is this. In all previous ages that I can think of the principal aim of rulers, except at rare and short intervals, was to keep their subjects quiet, to forestall or extinguish widespread excitement and persuade people to attend quietly to their several occupations. And on the whole their subjects agreed with them. They even prayed (in words that sound curiously old-fashioned) to be able to live 'a peaceable life in all godliness and honesty' and 'pass their time in rest and quietness'. But now the organization of mass excitement seems to be almost the normal organ of political power. We live in an age of 'appeals', 'drives', and 'campaigns'. Our rulers have become like schoolmasters and are always demanding 'keenness'. And you notice that I am guilty of a slight archaism in calling them 'rulers'. 'Leaders' is the modern word. I have suggested elsewhere that this is a deeply significant change of vocabulary. Our demand upon them has changed no less than theirs on us. For of a ruler one asks justice, incorruption, diligence, perhaps clemency; of a leader, dash, initiative, and (I suppose) what people might call 'magnetism' or 'personality' (Lewis 1969).
\end{abstract}

\title{
Augustus and the Problem of the Pax Deorum
}

In 9 B.C. the Roman province of Asia, hurried into action perhaps by the dedication of the Ara Pacis in Rome, finally got round to sending the Emperor Augustus an honorary crown. The politically active there had bandied this little idea about in the assembly for all of two decades; the occasion by now was not momentous. But with the crown came a rather more startling proposal from the Roman governor himself: the year, in those parts at least, was henceforth to begin on the birth date of Augustus. The text of presentation that accompanied the provincial crown is the usual Hellenistic servility -- men of the world gladly reduced to childlike dependence on a marvelous benefactor (Ehrenberg and Jones, Dittenberger 1905, Lewis and Reinhold 1966). The Roman governor's letter is different, thoughtful and oddly emotional:

"We could justly hold it (the birthday of Augustus) to be equivalent to the beginning of all things, and he has restored to serviceability, if not to its natural state, every form that had become imperfect and fallen into misfortune, and he has given a different aspect to the whole world, which blithely would have embraced its own destruction if Caesar had not been born for the common benefit of all. Therefore people would be right to consider this to have been the beginning of the breath of life for them, which has set a limit to regrets for having been born" (Johnson et al. 1961, Price 1984). ${ }^{1}$

Augustus was faced, during the central years of his reign, with the perplexing

\footnotetext{
${ }^{1}$ Price is better with the details than with the feeling of the evidence he handles in my view, but has some enlightening points to make about the role of Roman provincial magistrates in personalizing and even Romanizing the Hellenic view of Augustus.
} 
problem of changing from a 'leader' (in that sense of the word which my opening quotation used) into a 'ruler'. A leader, as long as he lives up to the demands of his trade, gives in himself definition to his followers. They are his. A ruler, on the other hand, if he is to accomplish anything must have a nation -- a people with somehow or other a definition of their own, a business to go about, a character of their own to express. When those things are dissociated from him and prove workable both the ruler and the people are far freer. He can regulate their business by the definition and judge them by it. If they stray from it he can try to recall them. They can (in theory) judge him by it as well. And all this is dependent, of course, on the definition being a livable, workable one. If the people cannot live by the definition without constantly betraying it, or alienating the gods of their experience, or being destroyed by outsiders or each other, then life is intolerable.

Octavian had been a leader. Augustus, once again, was faced with the problem of getting the Roman people to go back to being the Roman People when all the validity of that old definition seemed hopelessly discredited. Romans defined themselves by various kinds of authority and their pietas - their internal moral dedication and affection as well as their outward duty - toward it. But Roman law had lost the venerable old character it seemed to possess in the confident day of Polybius. Since the time of Sulla it seemed capable of accommodating any arbitrary conqueror's scheme of life and could change all out of recognition on a whim. Roman pietas had no longer any secure object -- Caesar, Pompey, Cicero, Brutus, Antony, Octavian all claimed real pietas was pietas toward them. They were Rome, and spoke with her exclusive authority no matter if they put their headquarters in Gaul or Greece, or began to resemble Asian demigods. Instead of the comforting old libertas (freedom because authority said one had it, and set the limits, and allowed one in return to have a certain say in the authority), there was the new liberty of a world without definition. One could, given the opportunity, do or say anything, but nothing that defined life in a world of Roman-ness was certain any more.

The young Octavian had flourished in that wild world. He rode his gift for improvisation and the practical skills of his friends to mastery of it. He also used propaganda, as the contestants in a world of splintered authority always will. But as he matured and found himself with a victory to consolidate he went through a rejection of the earlier factioned, formless era -- a rejection which increasingly resembled a religious conversion. Augustus came to be driven (often if we can trust his biographers to the point of exhaustion) by the belief that most of his world would disintegrate unless he could rebuild the life and fire in the old definition of Romanitas, put it back into his people, and make it endure. (Jeanmaire 1924, Scott $1933)^{2}$

\footnotetext{
${ }^{2}$ There was of course the Antonine alternative: a universalist, theocratic new model of empire without nationalisms or character after the imputed later fashion of Alexander. Rome was by any such scheme as likely as not to become just another province, or even a subsidiary one, for it should have to compete by less friendly rules with the sophisticated old cultures and better geo-political sites of the East. Antony and Cleopatra seem to have played this inferiority for all it was worth, as Mithridates had before them. In some sense this came true in the generations after Constantine, but my present point is how often writers on the propaganda wars often fail to note how widespread was the certainty in Cicero's day that the shift back to eastward was happening then. See e.g. Suetonius,
} 
Propaganda (which I understand strictly in this article as the repetition of a statement forcibly and by public demonstration until it begins to achieve actuality in the living world) was one of his best tools. Best, first of all, because he knew it well. His propaganda wars with Antony and the assassins in the forties and thirties of the previous era are too much written about to need any reintroduction here. (Charlesworth 1933, Scott 1933, Jeanmaire 1924, Tarn 1932) Many of the articles that treat them are so interested in (and suspicious of) the fact that he won the propaganda war that they fail to notice how much he began in the end to resemble and to be defined by the things he said about himself.

Because I want to concentrate on a few central acts of belief definition, 'propaganda' if you wish, during his central reign as Augustus, I have less space here to discuss this earlier growing re-definition (I had almost said "conversion") of Octavian's character. Aside from antagonism to Antony's Hellenistic theocracy and its cult of Alexander there were, I think, three parts to it. These were, briefly:

A tension in his adolescence between the enormously charismatic, capable Julius Caesar and his reliable, neo-conservative old guardian Philippus competing for the place of what moderns call a "father figure"3. Caesar won the early battles (in this war of definition by auctoritas) but Philippus had the final victory. The beginnings of a turning point in this struggle may be detectable during the crucial month of April, 44 B.C., when Octavian met his stepfather and mother in Cumae on the road to Rome, and his clash with destiny. Philippus had opposed his going to Rome, and continued doubtful that any good could come of taking up Caesar's legacy. The tone with which he introduced the young man to political acquaintances in the neighborhood is significant. "Octavius was with me here;" Cicero reported, "very complimentary and very friendly. His friends called him Caesar, but Philippus did not, and so I did not either" ${ }^{4}$. In the explosion of popular politics that followed, Philippus remained in the shadows. His only remaining major act (of which we are aware) was a religious dedication. An interesting result of this (traceable at length in a study of its own) is Octavian's gradual movement in choice of guardian deities from Alexander (of whom Caesar made so much), to Alexander's patron Hercules as conqueror (Antony had already appropriated Alexander's other deity Dionysus), thence toward Hercules as defender of common humanity and the human arts, (Mazzolani 1970, Dodds 1973) ${ }^{5}$ and so to

Julius Caesar lii, 3 and lxxix, 3. Lily Ross Taylor suggests both stories were part of the ecumenical propaganda of Antony (Divinity of the Roman Emperor (1931), p. $3 \mathrm{ff}$, and for the coins pp. $267 \mathrm{ff}$. and p. 122, no. 15. Cf. Plutarch, Antony, 4, 26, 33, 43, 36, 60. Dio Cassius XLVIII, xxxix, 2. Appian, Civil War, III, iii. Pompeius Trogus XXXVIII, v.

${ }^{3}$ Philippus had been father-in-law to Cato, and one of the consuls who in 56 opposed the candidacies (and general policies) of Pompey and Crassus, only to find themselves overwhelmed in the voting by Caesar's veterans. Cicero, Ad Att. IV, viiia, 2; Ad Quint. Frat. II, iv, 6. Dio Cassius XXXIX, xxvii-xxxi. Appian, Civil War II, xvii, xviii. Plutarch, Pompey 51-52; Crassus 14-15; Caesar 21; Cato 41-42. Philippus by all the accounts attempted to prevent Octavian joining the power-struggle in Rome after Caesar's death, but also made sure he had good "republican" advice when it became obvious where his ward was heading. Velleius Paterculus II, lix-lx. Appian, Civ. Wars III, ii. On Philippus' political complexion in general, see Gruen (1974, pp. 146 f., 296 f., 334 f).

${ }^{4}$ Cicero, Ad Att. XIV, xii, 2.

${ }^{5}$ The trail of comparative character attributed to Hercules here can be traced through the Hellenistic 
the Muses, and finally to Apollo. The last stages of this journey were very likely due to Philippus, who under the Augustan programme of temple restoration chose to build his own to Hercules and the Muses. ${ }^{6}$ To Apollo I shall very shortly return.

Secondly, Augustus found himself defined by his role as the Avenger of Caesar. On the surface this is obvious -- Octavian needed the pose for legitimacy and respect as he built up his power in the early years. And yet wouldn't Caesar's avenger be expected to reinstate his policies to stay legitimate? Augustus was forced by his increasing belief in the romantic old values of neo-conservatives like Philippus and Cicero to opt instead for the role of avenger pure and simple. The stain of Caesar's death had to be cleansed for reasons other than the rightness of his plans for Rome. An answer to this dilemma was part of the third factor.

At the center of the things that drove Augustus throughout his life was a deep and increasing anxiety about the state of pax deorum -- both his and Rome's. Warde Fowler, who has seldom been bettered on such subjects, once defined this in a way that seems especially compatible with Augustus' behavior. For the purposes of this article, the phrase pax deorum will mean:

"... -- the right relation between man and various manifestations of the Power, ... and the machinery by which it was secured was the ius divinum. We shall not be very far wrong if we say that it was Augustus' aim to re-establish the pax by means of the ius; ... the idea that unless the divine inhabitants were properly propitiated, they would not do their part in supporting the human inhabitants in all their doings and interests" (Fowler 1911: 431). ${ }^{7}$

Just why Augustus nurtured so primary an anxiety (and at the end of his life perhaps a pessimism) in this matter is a large question, but I offer a few brief suggestions. A person naturally prone to accident and sickness would in the classical world have been exposed to a great deal of talk about his relationship to the divinities -- it would have started young and continued throughout his life. Then, too, the antiquarian but rather Hellenized neo-conservative movement to which Philippus, Cicero and Maecenas belonged placed a high value on the piety of the rural Italians who were still scrupulous about the gods of farm and hearth. Even if the gods were figments (as Cicero seemed sometimes willing to believe) the old attitudes were conducive to those bluff, honest, frugal virtues that were supposed to have made Rome great. And the survival of those as targets of living belief in the world after Actium was perhaps evidence in turn that the gods did exist.

That same group of semi-antiquarian social critics was also conscious of a

and into the classical era. Cf. Cicero, de Officiis III, v, 25; Isocrates, Philippics, 109; Plato, Symposium, 177B. Seneca, de Beneficiis I, xiii, 1-3 suggests the emotional image was transmitted, still consistently, to the later Julio-Claudian world.

${ }^{6}$ Suetonius, Augustus, 29.

${ }^{7}$ Another remark from the same context is worth quoting as well, since it strikes Augustus' own maneuvering on the borderlands of divinity with a fine and unpolitical stress: "the new element [the divinity of Augustus] may be defined as in Rome (and in Italy too, as far as his own wish could limit it) nothing more than the encouragement of the belief in him, and loyalty to him as the restorer of the pax deorum", p. 438. Nothing more is claimed in the Res Gestae than that. 
new sense of guilt or sin in the fabric of human society, real or imagined, that seems to have seeped into the air of Italy steadily since the age of Sulla and the Gracchi (Ogilvie 1969) ${ }^{8}$. In tumultuous times it was all very well to make heroes of suicides to principle like Cato, but it left those still living in quieter years uncomfortably aware that they had betrayed friends, or vows or principles of their own, or simply hidden away to avoid similar fates. The poet Horace, at once a distant friend of, and daring critic of, the new regime had a habit of sounding this note periodically and pointedly among his chattier and more personally reflective publications:

Roman you will pay for your forefathers' sins

Till you rebuild gods' temples from ruins,

Roofs of worm-eaten oak,

Statues filthy with smoke.

To be below the gods your rule defends

To this fix all beginnings and all ends.

Gods take a heavy fee

From wailing Italy...

Augustus seems not only to have undergone a conversion of his own on matters of deity and definition of life, but to have shared with this group an interest in the general subject. The pax deorum of Rome itself needed healing. He set more store by his own initiation into the Eleusinian mysteries than one might have expected from a Roman of his public character (Jones 1970) ${ }^{10}$. A similar initiation, on Italian soil, appeared for the purification of the hero of the Aeneid, a poem which must have been much discussed at every stage of its composition in the Augustan circle (Fowler 1911, Mazzolani 1970) ${ }^{11}$.

And at the end of all this were created, as its solution, the Ludi Saeculares of 17 B.C. "Games" is translation of "ludi" in this case which misses the whole significance of the phenomenon, and "festival" is not much better. My aim in the sequel study to this - the study for which this sets the stage - is to examine the attempt by Augustus to achieve the phenomenon itself by a very familiar kind of spiritual engineering. What he would achieve in fact can be followed in the social history of his later reign, and the scandals surrounding names like Julia, Tiberius and Ovid are the beginnings of the critique of that achievement.

\footnotetext{
${ }^{8}$ Even in the view of a commentor so detached as Horace: "You will pay for the sins of your ancestors [delicta maiorum], Romans, until you repair the ruined temples of the gods, and the images begrimed with smoke", Odes III, vi, 1. For a tangible example of Horace's worry, Nepos, Atticus XX, 3. The theme is a recurrent one in Livy, sometimes breaking into conscious "asides" (III, xx, 5; VI, xli, 8).

${ }^{9}$ Horace, Odes, III, vi, 11 1-8, the translation this time from P. Levi, Horace: a Life (New York, 1998).

${ }^{10}$ Jones also quotes, without fully catching its spirit, the stanza from the Carmen Saeculare in which Horace (or better Augustus, I suspect) agonizes over "generations fertile in guilt" and almost manages to drag the lex maritandis visibly into the worship. The bachelors of the Roman political elite, after all, were present for once.
} 


\section{A Note on the Purpose of This Study, Here and in the Parts Following}

Over the last, largely secularizing, century of classical scholarship the disagreements of Christian and non-Christian scholars in the study of ancient religion have been - unsurprisingly - numerous. To my eye at least, what have been far more curious have been some of the points on which Christian and nonChristian classical scholarship have seemed contented to agree.

The purpose of this study is to examine, using as lenses a series of small, related test cases clustered all round one of these interesting but seemingly noncontroversial issues, and to ask whether, in the magnanimity of their agreement, scholars (including those attempting to operate from a perspective in which a culture's faith definitions taken as important or even critical rather than as distanced curios) have not missed a critical point or two in the nature of the human being, and of ancient Greco-Roman religious belief, and - particularly - in the relevance of the early Christian understanding of those two and how it has affected the way we write about, the way we think we analyze the Classical era.

The particular target on which I hope to concentrate a few experimental spotlights is that complex of beliefs, doctrines and feelings that revolve around the Christian (and covenantal Judaic or even Islamic) idea of $\sin$ - sin itself propter, guilt, repentance, contrition, absolution and renewal. There was a great deal of talk about these in the classical Greek, and especially the classical Roman worlds, but almost every major text on the internal religious feelings of either culture, or of the two combined, assure us that we must not understand ancient Greek or Roman religious acts or talk about these issues in Christian terms, or even in terms that Christian thinkers would find natural. "Whoever tries to measure ancient religion by Christian yardsticks will be deceive himself or retire baffled," remarks Eric Robertson Dodds in one of the classic simple pontifical introductions to the subject (and by a scholar unusually sensitive to nuances of belief in which ancient Christian and non-Christian hearts really did seem to be responding to the same things in the same way). He goes on...

"There are large areas of Christian experience which have no true counterpart in the classical age of Greece. For example, the concepts of sin and redemption, central in Christianity, are simply missing from the vocabulary of that age: there are plenty of words for 'guilt' and 'wrongdoing,' but if we translate them 'sin' we nearly always import a false implication" (Dodds 1972: 140). ${ }^{12}$

I could unnecessarily multiply this confident assertion with an echo from the introduction to almost any other modern text on the religious world in which Christianity first appeared. The cumulative effect on students of the interaction between paganism and early Christianity has been predictable: both Christian and non-Christian scholars generally begin somewhere close to the assumption that Christianity had first to create the sense of sin and the need for an experience of redemption in its audience of potential converts, and then to satisfy it once it had been created. Fundamentalist classical scholarship has often concentrated

\footnotetext{
${ }^{12}$ Other concepts similarly false when 'imported' into the ancient religious understanding include any concept of love between God or gods and humankind, and any internal record of religious growth in the manner of Augustine or Kierkegaard.
} 
consequently on the fact of $\sin$ in the classical Roman or Greco-Roman lifestyle (frequently with luridly exaggerated details) and then emphasized the 'bully' style of preaching when it could be found among the most aggressively vocal of the early church fathers. More 'liberal' Christian scholarship has, like most postmodernist study of religion, tended toward emphasizing the aesthetic 'transformation' (a favorite word) of ancient religious feeling or experience by early Christian miracles, moral or hagiographical preaching, heroes or ritual.

Everett Ferguson, author of the most literate and nuanced recent survey of ancient religion and the environment of belief in which Christianity arose, makes or tries to make - this lack of a sin-concept a positive distinctive in Christianity, arguing insistently that the ancient was so clueless about guilt and redemption that even penitential and regenerative rituals like the various 'mysteries' popular both in classical Greece and the early Roman empire were in their essence unconnected with 'moral renewal', and that (unlike Christian baptism) nothing in these ceremonies of purification and rebirth effected any but a few of the most intellectual pagan consciences (Ferguson 1993: 280ff).

\section{Conclusions}

To re-examine all of that might require a book. My proposal here is more modest - to suggest we have been too quick to make those assumptions, and to look in the second and third parts of this study at a few episodes in the career of the Roman reformer and emperor Augustus as he attempted in his later career to find ways to stabilize or protect his new empire. Bearing this scholarly agreement in mind, we may find it might have startled Augustus. It should not be necessary to point out that we will be examining a period prior to (but only a fraction earlier than) the great formative events described in the Christian gospels, that we are examining a period that must have made its religious definitions and commitments without being influenced by them.

\section{Acknowledgements}

This material written for presentation at the ATINER $13^{\text {th }}$ Annual International Conference on History \& Archaeology: From Ancient to Modern, June-July 2015, and revised with feedback from that presentation. My thanks to all who contributed, however informally. 


\section{References}

\section{Modern References}

Charlesworth MP (1933) Some Fragments of the Propaganda of Mark Antony. Classical Quarterly 27(3/4): 172-177.

Dittenberger W (1905) Orientis Graeci Inscriptiones Selectae [Corpus posts Selections]. Leipzig: Hirzel.

Dodds ER (1972) The Ancient Concept of Progress. Oxford: Clarendon Press.

Ehrenberg V, Jones AHM (1949) Documents Illustrating the Reigns of Augustus and Tiberius UK: Oxford UP.

Ferguson E. (1993) Backgrounds of Early Christianity. Grand Rapids: Eerdmans.

Fowler WW (1911) Religious Experience of the Roman People. Fili-Quarian Classics.

Gruen E (1974) The Last Generation of the Roman Republic. Berkeley: University of California Press.

Jeanmaire H (1924) La Politique Religieuse d'Antoine et Cléopatre [The religious policy of Antoine and Cleopatra]. Revue Archéologique 19: 241-261.

Johnson AC, Coleman-Norton P, Bourne F (eds) (1961) Ancient Roman Statutes. Austin: University of Texas Press.

Jones AHM (1970) Augustus. New York: W.W. Norton \& Company.

Levi P (1998) Horace: a Life. New York: Tauris Parke Paperbacks.

Lewis CS (1969) De Descriptione Temporum [Description of the Times]. Cambridge: Cambridge University Press.

Lewis N, Reinhold M (eds) (1966) Roman Civilization. New York: Columbia University Press.

Mazzolani LS (1970) The Idea of the City in Roman Thought. Indiana: Indiana University Press.

Ogilvie RM (1969) The Romans and their Gods in the Age of Augustus. New York: W.W. Norton \& Company.

Price SRF (1984) Rituals and Power: the Roman Imperial Cult in Asia Minor. Cambridge: Cambridge University Press.

Scott K (1933) The Political Propaganda of 44 - 30 B.C. Bergamo: American Academy in Rome.

Tarn WW (1932) Alexander Helios and the Golden Age. Journal of Roman Studies 22(2): 135-160.

Taylor LR (1931) Divinity of the Roman Emperor. Ayer Co Pub.

Ancient References (each locus in notes as appropriate)

Appian, Civil Wars

Augustus, Res Gestae

Cicero, Ad Atticus, Ad Quintus, De Officiis,

Dio Cassius, Histories

Horace, Odes

Livy, Histories (esp bk. III)

Nepos, Lives (esp. Atticus)

Plutarch, Antony, Pompey, Crassus, Caesar, Cato

Pompeius Trogus, History of Rome

Seneca, de Beneficiis

Suetonius, Augustus, Julius Caesar

Velleius Paterculus, History of Rome 
